\title{
Effect of oxytocin infusion on secretion of progesterone and luteinizing hormone and the concentration of uterine oxytocin receptors during the periovulatory period in cloprostenol-treated ewes
}

\author{
D. C. Wathes*, E. L. Matthews and V. J. Ayad \\ Department of Anatomy, School of Medical Sciences, Bristol BS8 1TD, UK
}

\begin{abstract}
Summary. Oxytocin infusions were initiated on day 10 of the oestrous cycle in ewes, and luteal regression was induced by injection of $100 \mu \mathrm{g}$ cloprostenol on day 12 . Blood samples were collected at frequent intervals via an indwelling jugular vein cannula to measure concentrations of progesterone and luteinizing hormone $(\mathrm{LH})$ during the luteal and follicular phases in saline $(n=6)$ and oxytocin $(n=5)$ infused animals. The oxytocin infusion maintained peripheral plasma concentrations of $53 \pm 3.2 \mathrm{pg}$ oxytocin $\mathrm{ml}^{-1}$ (mean $\pm \mathrm{SEM}$ ) compared with values of about $1 \mathrm{pg} \mathrm{ml}^{-1}$ during oestrus in control ewes. Oxytocin infusion had no effect on luteal phase progesterone concentrations, the timing of luteolysis, basal luteinizing hormone (LH) secretion, LH pulse frequency, or the timing or height of the LH surge. Treated ewes came into oestrus significantly earlier than controls $(P<0.05)$ but ovulated normally. Uterine samples collected $96 \mathrm{~h}$ after cloprostenol injection (approximately day 2 of the cycle) showed that oxytocin receptor concentrations were significantly higher in the endometrium in ewes that had been given a 5 day oxytocin infusion than in control animals (556 and

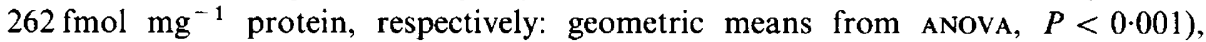
whereas myometrial receptor concentrations were not affected (113 and $162 \mathrm{fmol} \mathrm{mg}^{-1}$ protein, respectively).

We conclude that the previously reported delay in luteal development caused by oxytocin infusion (Wathes et al., 1991) is not due to the inhibition or delay of ovulation, but must instead occur via a direct influence on the developing corpus luteum. Our results differ from those in rodents in which higher doses of oxytocin have been shown to influence both LH secretion and the timing of ovulation. Prolonged infusion with oxytocin at the dose used (the high end of the normal physiological range) during the periovulatory period does not cause downregulation of the oxytocin receptor.
\end{abstract}

Keywords: ewe; oxytocin; gonadotrophins; oxytocin receptors; ovulation; cloprostenol

\section{Introduction}

The corpus luteum is a major contributor to the circulating concentration of oxytocin during the oestrous cycle of ewes (Flint \& Sheldrick, 1982; Wathes \& Swann, 1982). The best established role for oxytocin is in the regulation of uterine prostaglandin $\mathrm{F}_{2 \alpha}\left(\mathrm{PGF}_{2 \alpha}\right)$ secretion during luteolysis (McCracken et al., 1984; Auletta \& Flint, 1988) but a number of other functions have been suggested including influences on steroidogenesis (Tan et al., 1982), reproductive tract motility

\footnotetext{
*Present address: AFRC Institute of Animal Physiology and Genetics Research, Babraham, Cambridge CB2 4AT,
} UK. 
(Gilbert et al., 1992) and gonadotrophin secretion (Martini et al., 1959). Work in rodents has shown that oxytocin treatment can influence the timing of follicular development and of the LH surge (Robinson et al., 1985; Evans et al., 1989), whereas subcutaneous injection of oxytocin into rabbits shortly before mating blocked ovulation (Brinkley \& Nalbandov, 1963). It is uncertain whether these effects were mediated directly on the ovary or indirectly via the pituitary, as there is evidence that oxytocin can act as a releasing factor for $\mathrm{LH}$ from rat pituitary cells in culture (Evans \& Catt, 1989).

We have previously shown that both active immunization against oxytocin and infusion with oxytocin block the establishment of pregnancy in ewes (Wathes et al., 1989, 1991). The immunization procedure increased gonadotrophin secretion during both the luteal and follicular phases of the oestrous cycle, although the height and timing of the LH surge were unaffected. The free (unbound) oxytocin concentration in the circulation was also raised. Infusion with oxytocin during the follicular and early luteal phase following $\mathrm{PGF}_{2 \mathrm{a}}$-induced luteolysis delayed the subsequent rise in plasma progesterone concentrations by about 3-4 days. The main aim of the present experiment was to characterize the events around ovulation in more detail to determine whether oxytocin infusion in ewes altered either the gonadotrophin secretion pattern or the timing of ovulation.

The concentration of oxytocin receptors in the reproductive tract of ewes is regulated principally by the steroids oestradiol and progesterone (McCracken et al., 1984; Sheldrick \& Flint, 1985; Vallet et al., 1990). However, the uterus is exposed to continuously high concentrations of oxytocin throughout the luteal phase of the cycle, and in rats continuous infusion with oxytocin decreases the myometrial receptor concentration (Engstrom et al., 1988a, b). In ewes oxytocin infusion from day 13 of the cycle prevents the formation of oxytocin receptors, which normally develop on day 14, and hence delays luteolysis (Flint \& Sheldrick, 1985). We therefore investigated whether infusion of oxytocin had any effect on its own receptor concentration in a situation in which the steroid hormone background had been altered by cloprostenol treatment.

\section{Materials and Methods}

\section{Animals and treatment protocol}

Oestrus was synchronized in 18 mature Clun Forest ewes by intravaginal Veramix sponges (Upjohn Ltd, Crawley, West Sussex, UK) inserted for 11 days. Ewes were run with a vasectomized ram and 12 animals were selected that had been raddled between $24-48 \mathrm{~h}$ after sponge removal (day of oestrus $=$ day 0 ). These animals were transferred to pens inside and fed concentrate mix once daily with hay and water available ad libitum.

Jugular vein cannulae were inserted on day 9 of the cycle. On day 10 at $17.00 \mathrm{~h}$, Alzet minipumps 2001 (Alza Corporation, Palo Alto, California, USA) containing either vehicle (saline, $0.9 \%(\mathrm{w} / \mathrm{v}) \mathrm{NaCl}$ containing $0.01 \%$ acetic acid, $n=6)$ or oxytocin solution $\left(6 \mathrm{mg}\right.$ oxytocin $\mathrm{ml}^{-1}$ vehicle, Hoechst, Frankfurt, Germany, $\left.n=6\right)$ were inserted s.c. on the dorsal surface of the neck under local anaesthesia. The pumps had been loaded under sterile conditions on the previous day, stored desiccated overnight at $4^{\circ} \mathrm{C}$ and placed in $5 \mathrm{ml}$ sterile saline at $37^{\circ} \mathrm{C}$ for $4 \mathrm{~h}$ before insertion. On day 12 at $9.00 \mathrm{~h}$ all ewes were given a single injection of cloprostenol $\left(100 \mu \mathrm{g}\right.$ i.m., prostaglandin $F_{2 \mathrm{a}}$ analogue (PG); Coopers Animal Health Ltd, Crewe, Cheshire, UK) to induce oestrus. They were tested for oestrus with a vasectomized ram on the evening of day 13 and every $2 \mathrm{~h}$ from $9.00 \mathrm{~h}$ on day 14 ( $48 \mathrm{~h}$ after PG). Ewes were slaughtered $96 \mathrm{~h}$ after PG for collection of the reproductive tract and ovaries.

\section{Blood sampling procedure}

Jugular vein blood samples $(10 \mathrm{ml})$ were collected once a day via vacutainers or indwelling cannulae on days 2,4 , 6,9 and 12 for estimation of the progesterone and oxytocin concentration by radioimmunoassay. More frequent window bleed samples $(2,10 \mathrm{or} 20 \mathrm{ml})$ were collected via the cannulae every $15 \mathrm{~min}$ for $8 \mathrm{~h}$ starting at $9.00 \mathrm{~h}$ on each of days 10 (window bleed 1, mid-luteal phase pre-infusion), 11 (window bleed 2, luteal phase, during infusion) and 13 (window bleed 3, follicular phase during infusion) for measurement of progesterone (every $1 \mathrm{~h}$ ), oxytocin ( 2 samples at $11.00 \mathrm{~h}$ and $15.00 \mathrm{~h}$ ), and LH (every $15 \mathrm{~min}$ ). Samples were also collected for determination of FSH but were damaged by a freezer failure. From day 14 onwards ( $48 \mathrm{~h}$ after PG, day of induced oestrus) blood samples were collected every $3 \mathrm{~h}$ for measurement of $\mathrm{LH}$ (to detect the time of the preovulatory surge) and twice daily for progesterone and oxytocin measurement. 
All blood samples were collected into heparinized tubes on ice and centrifuged ( $1500 \mathrm{~g}$ for $15 \mathrm{~min}$ ) within $20 \mathrm{~min}$ of collection. Plasma was divided into separate aliquots, frozen on solid $\mathrm{CO}_{2}$ and stored at $-20^{\circ} \mathrm{C}$ for progesterone and $\mathrm{LH}$ radioimmunoassay and $\mathrm{at}-80^{\circ} \mathrm{C}$ for oxytocin radioimmunoassay.

\section{Tissue collection}

Ewes were killed by an overdose of Euthatal (RMB Animal Health Ltd, Dagenham, UK) i.v. and the reproductive tract was immediately removed. The ovaries were examined and all corpora lutea and follicles $>4 \mathrm{~mm}$ in diameter were dissected out and placed in Bouin's fixative. Wax embedded sections $(10 \mu \mathrm{m})$ were stained with haematoxylin and eosin and examined by light microscopy.

The uterus was divided into four regions: left and right horn and left and right body. For each region, all the endometrium and myometrium was dissected as described previously (Ayad \& Wathes, 1989), and stored in liquid $\mathrm{N}_{2}$ for subsequent estimation of oxytocin receptor concentration. The method used for preparation of crude endometrial and myometrial membrane fractions was similar to that described previously (Ayad \& Wathes, 1989) with some slight modifications (Ayad et al., 1991). The relative binding of a saturating concentration of $\left[{ }^{3} \mathrm{H}\right]$ oxytocin $\left(5-10 \mathrm{nmol} 1^{-1}\right)$ to membrane fractions $(25-50 \mu \mathrm{g}$ protein per tube) was measured as an estimate of oxytocin receptor concentrations. All samples were incubated in the same experiment and each sample was assayed twice. The affinity of binding was also measured in three endometrial samples from oxytocin-infused ewes. Specific binding to endometrial membranes $\left(30 \mu \mathrm{g}\right.$ per tube) at ten different concentrations of $\left[{ }^{3} \mathrm{H}\right]$ oxytocin $\left(0 \cdot 04-20 \mathrm{nmol} \mathrm{1}^{-1}\right)$ was measured to generate a binding isotherm. The dissociation constant $\left(K_{\mathrm{d}}\right)$ was calculated using the computer program POLYFIT. Intra- and interassay coefficients of variation for the receptor measurements were $23 \%$ and $25 \%$, respectively.

\section{Radioimmunoassays}

Progesterone. Progesterone measurements were performed on $0.25 \mathrm{ml}$ aliquots of plasma using petroleum ether extraction as described previously (Wathes et al., 1986). The detection limit was $0.2 \mathrm{pg} \mathrm{ml}^{-1}$, the extraction efficiency was $68 \pm 3.0 \%$ and the intra- and interassay coefficients of variation were 13.8 and $20.6 \%$, respectively.

Oxytocin. Oxytocin measurements were made after extraction of approximately $4 \mathrm{ml}$ plasma on C18 cartridges (Jones Chromatography Ltd, Hengoed, Mid Glamorgan, UK) as described previously (Wathes et al., 1991). The limit of sensitivity was $0.5 \mathrm{pg} \mathrm{ml}^{-1}$ and the intra- and interassay coefficients of variation were $3.3 \%$ and $2.5 \%$, respectively.

Lateinizing hormone. LH measurements were made using the specific double-antibody radioimmunoassay of Foster \& Crighton (1974) as modified by McLeod et al. (1982). The limit of sensitivity was 0.1 ng NIH-LH-S24 equivalent $\mathrm{ml}^{-1}$ plasma and the intra- and interassay coefficients of variation were $8 \cdot 3$ and $9 \cdot 8 \%$, respectively.

\section{Statistical analysis}

The hormonal data were analysed by ANOVA allowing for repeated measures over time from the same animal with oxytocin infusion as the experimental factor. The onset of the preovulatory LH surge was considered to be the time when concentrations first exceeded $3.0 \mathrm{ng} \mathrm{ml}^{-1}$. An LH rise was considered to be a pulse if the value of two consecutive samples was greater than the mean of the two previous samples (basal value) and the value of at least one of the peak samples exceeded the mean basal value by more than four times the intra-assay coefficient of variation of the assay (Wallace et al., 1988). The timing of the onset of oestrus was compared using the Mann-Whitney U test. The uterine receptor concentrations were analysed by ANOVA using a repeated measures design to correct for differences between sheep. Hormone infusion, endometrium versus myometrium, right versus left sides and body versus horn were included as experimental factors. The data were not normally distributed and were therefore subjected to a logarithmic transformation.

\section{Results}

One oxytocin-infused ewe did not undergo luteolysis in response to the cloprostenol injection and this animal was excluded from all the analyses.

After insertion of the osmotic minipumps on the afternoon of day 10 of the cycle oxytocin concentrations increased to $62 \pm 7.5 \mathrm{pg} \mathrm{ml}^{-1}$ on day 11 (mean $\pm \mathrm{SEM}$ ) in treated ewes in comparison to $4.0 \pm 1.0 \mathrm{pg} \mathrm{ml}^{-1}$ in controls. In oxytocin-infused animals, oxytocin concentrations remained high throughout the remainder of the experiment with a mean value of $53 \pm 3 \cdot 2 \mathrm{pg} \mathrm{ml}^{-1}$ and a range of 23-124 $\mathrm{pg} \mathrm{ml}^{-1}$, whereas in control ewes values decreased to about $1 \mathrm{pg} \mathrm{ml}^{-1}$ following luteolysis (Fig. 1).

Luteal phase progesterone concentrations were not influenced by treatment. The window bleed values from day 10 (before pump insertion) and day 11 (starting $18 \mathrm{~h}$ after pump insertion) were 

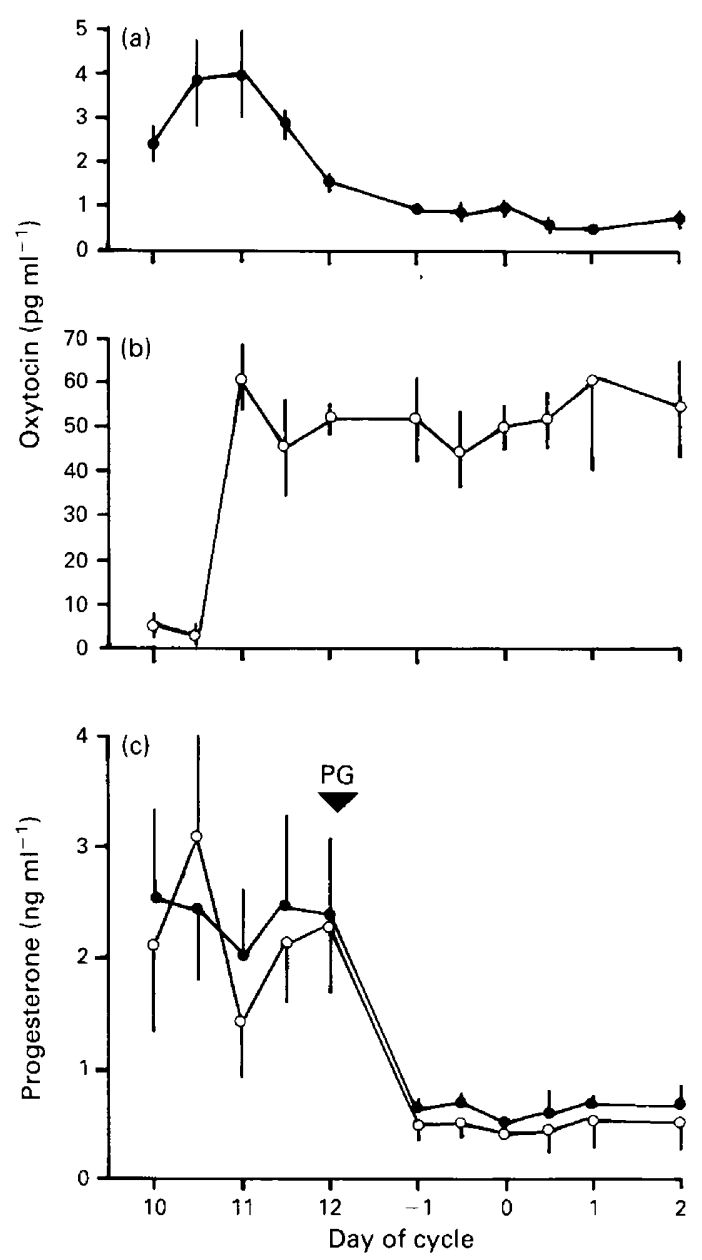

Fig. 1. Oxytocin (a and b) and progesterone (c) profiles from control saline-infused $(\bullet, n=6)$ and oxytocin-infused $(O, n=5)$ ewes during cloprostenol $(\mathrm{PG})$-induced luteolysis. Values are means \pm SEM.

$2 \cdot 3 \pm 0.22$ and $2 \cdot 1 \pm 0.21 \mathrm{ng} \mathrm{ml}^{-1}$ in control ewes and $2.4 \pm 0.22$ and $2.0 \pm 0.22 \mathrm{ng} \mathrm{ml}^{-1}$ in oxytocin-infused animals ( $n=8$ samples on each day). The timing of the fall in progesterone after cloprostenol treatment was also unaffected (Fig. 1).

LH concentrations were measured before and after oxytocin infusion during the luteal phase, during the follicular phase from 24-32 h after cloprostenol injection and during the LH surge. Neither the LH concentration, pulse frequency, surge timing, nor surge height were influenced by oxytocin treatment (Table 1 and Fig. 2). The intervals from cloprostenol injection to the start of the surge were $59 \pm 3.0$ and $58 \pm 2.4 \mathrm{~h}$, respectively, in control and treated animals, whereas LH surge heights were $32 \cdot 2 \pm 3.46$ and $30.2 \pm 8.43 \mathrm{ng} \mathrm{ml}^{-1}$, respectively.

No ewes were in oestrus $36 \mathrm{~h}$ after the cloprostenol injection. They were subsequently tested at $48 \mathrm{~h}$ when all five oxytocin-infused animals were in standing oestrus, compared with only one control ewe. The remaining five control animals came into oestrus between 51 and $57 \mathrm{~h}$ after injection. This difference was significant $(P<0.05)$.

Ewes were killed $96 \mathrm{~h}$ after the cloprostenol injection and approximately $38 \mathrm{~h}$ after the start of the LH surge (equivalent to day 2 of the oestrous cycle, where day of oestrus is day 0 ). All ewes in 
Table 1. Concentrations of luteinizing hormone ( $\mathrm{LH})$ in control and oxytocin-infused ewes during the luteal and follicular phases of the oestrous cycle

\begin{tabular}{|c|c|c|c|c|c|c|}
\hline & \multicolumn{2}{|c|}{ Luteal phase pre-infusion } & \multicolumn{2}{|c|}{ Luteal phase during infusion } & \multicolumn{2}{|c|}{ Follicular phase } \\
\hline & Control & $\begin{array}{l}\text { Oxytocin- } \\
\text { infused }\end{array}$ & Control & $\begin{array}{l}\text { Oxytocin- } \\
\text { infused }\end{array}$ & Control & $\begin{array}{l}\text { Oxytocin- } \\
\text { infused }\end{array}$ \\
\hline $\begin{array}{l}\text { LH concentration } \\
\left(\mathrm{ng} \mathrm{ml}^{-1}\right)\end{array}$ & $0.31 \pm 0.015$ & $0.33 \pm 0.012$ & $0.34 \pm 0.020$ & $0.35 \pm 0.079$ & $0.46 \pm 0.015$ & $0.55 \pm 0.015$ \\
\hline $\begin{array}{l}\text { LH pulse height } \\
\left(\mathrm{ng} \mathrm{ml}^{-1}\right)\end{array}$ & $0.75 \pm 0 \cdot 10$ & $0.65 \pm 0.04$ & $0.91 \pm 0.15$ & $0.93 \pm 0.32$ & $0.80 \pm 0.05$ & $0.79 \pm 0.03$ \\
\hline LH pulses (in $8 \mathrm{~h}$ ) & $2.2 \pm 0.31$ & $2.0 \pm 0.45$ & $2.2 \pm 0.31$ & $2.2 \pm 0.37$ & $4.8 \pm 0.60$ & $5.4 \pm 0.24$ \\
\hline
\end{tabular}

All values are means \pm SEM. There were no significant differences between control and treated animals.
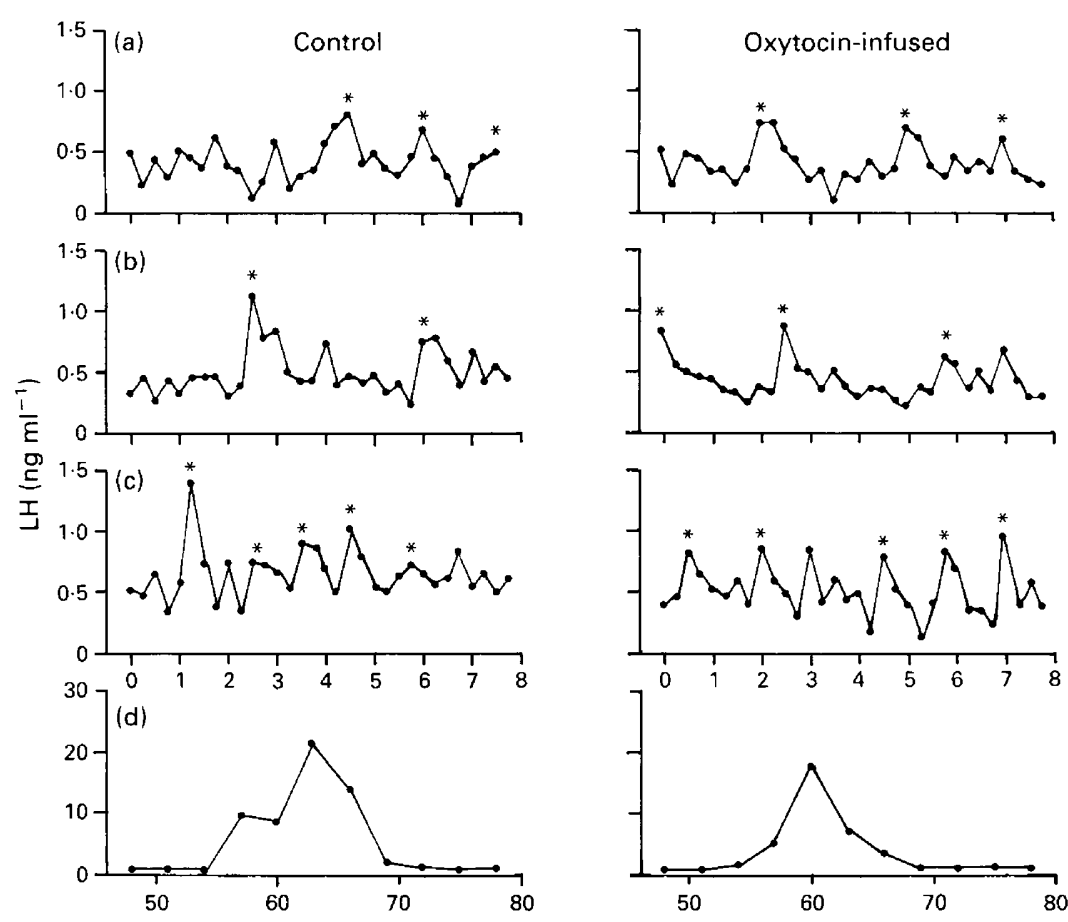

Time (h)

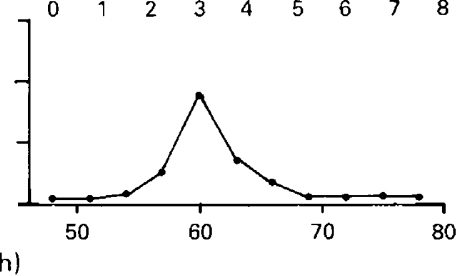

Fig. 2. Examples of representative luteinizing hormone $(\mathrm{LH})$ profiles from one control and one oxytocin-infused ewe during (a) midluteal phase pre-infusion (window bleed 1); (b) midluteal phase during infusion (window bleed 2); (c) early follicular phase starting $24 \mathrm{~h}$ after PG injection (window bleed 3 ) and (d) follicular phase starting $48 \mathrm{~h}$ after PG injection. Samples for $(\mathrm{a}-\mathrm{c})$ were collected every $15 \mathrm{~min}$ and for (d) every $3 \mathrm{~h}$. The detection limit of the assay was $0.1 \mathrm{ng}$ $\mathrm{ml}^{-1}$. Significant pulses of LH are shown by stars.

both groups had ovulated, with identical ovulation rates of $2 \cdot 0 \pm 0.0$ and $2 \cdot 0 \pm 0 \cdot 31$, respectively. The young corpora lutea all appeared histologically normal and there were no obvious differences between the control and oxytocin-infused animals. Plasma oxytocin concentrations in control and treated animals were $0.8 \pm 0.17$ and $54.0 \pm 11.73 \mathrm{pg} \mathrm{ml}^{-1}$, respectively, and progesterone values were $0.6 \pm 0.19$ and $0.5 \pm 0.22 \mathrm{ng} \mathrm{ml}^{-1}$, respectively, in samples collected just before the ewes were killed. 
Uterine oxytocin receptor concentrations were also measured on day 2. There were no significant differences in concentrations for either the endometrium or myometrium between the four different regions studied (left and right sides of the uterine body and horn, respectively). Endometrial concentrations were greater than myometrial concentrations in both control and treated animals $(P<0.01$ and $P<0.001$, respectively, Table 2$)$. There was no difference in the overall myometrial receptor concentration between control and treated ewes. However, single site analysis of endometrial oxytocin receptor concentrations showed that these were significantly higher in the oxytocin-infused ewes $(P<0 \cdot 01$, Table 2$)$. The kinetics of $\left[{ }^{3} \mathrm{H}\right]$ oxytocin binding to the endometrium of the three oxytocin-infused ewes with the highest apparent receptor concentrations were assessed in more detail. Binding was found to be to a single site over the concentration range studied with a mean $K_{\mathrm{d}}$ value of $2.4 \pm 0.86 \mathrm{nmol}^{-1}$ (mean \pm SEM). These properties are similar to those previously reported for the ovine oxytocin receptor (Sheldrick \& Flint, 1985; Ayad \& Wathes, 1989) and so any effect of oxytocin infusion was probably on the concentration rather than the affinity of oxytocin receptors.

Table 2. Concentrations of oxytocin-binding sites at different regions of the ovine uterus two days after cloprostenol-induced oestrus ${ }^{\mathrm{a}}$

\begin{tabular}{lcc}
\hline & $\begin{array}{c}\text { Control } \\
(n=6)\end{array}$ & $\begin{array}{c}\text { Oxytocin-infused } \\
(n=5)\end{array}$ \\
\hline Endometrium & $262^{\mathrm{a}}$ & $556^{\mathrm{b}}$ \\
& $(2 \cdot 42)$ & $(2 \cdot 74)$ \\
Myometrium & $162^{\mathrm{c}}$ & $113^{\mathrm{c}}$ \\
& $(2 \cdot 21)$ & $(2 \cdot 05)$ \\
\hline
\end{tabular}

${ }^{a}$ Concentrations are given as the geometric means with the log values in parentheses. ANOVA was performed on the log values and the SEDs for statistical comparisons were as follows: control endometrium versus oxytocininfused endometrium, $0 \cdot 116$; control myometrium versus oxytocin-infused myometrium, 0.116 ; control endometrium versus control myometrium, 0.077 and oxytocin-infused endometrium versus oxytocininfused myometrium, $0 \cdot 085$.

b $>$ a,$P<0.01 ;$ a $>$ c, $P<0.01 ;$ b $>$ c,$P<0.001$.

\section{Discussion}

Oxytocin is a major product of the ruminant corpus luteum, and the inhibition of oxytocin receptor formation is a critical event in early pregnancy (for reviews see Auletta \& Flint, 1988; Wathes, 1989). The main aims of this study were first to provide further information about the mechanisms by which both active immunization against oxytocin (Wathes et al., 1989) and infusion of oxytocin (Wathes et al., 1991) prevent ewes from becoming pregnant, and secondly, to investigate a potential role for oxytocin in the regulation of its own receptor. We observed previously that immunization against oxytocin increased the concentration of LH and FSH during both luteal and follicular stages of the cycle, although the timing and height of the LH surge were not affected (Wathes et al., 1989). A number of previous studies in various species and both sexes have addressed the question of whether exogenous oxytocin treatment has a direct influence on gonadotrophin secretion, most reporting no effect (for review see Wathes, 1984). More recent work on rodents has shown that treatment of pro-oestrous rats with oxytocin or its antagonists in vivo can influence $\mathrm{LH}$ release 
(Johnston \& Negro-Villar, 1988; Robinson \& Evans, 1990) and oxytocin also acted as a releasing agent for LH from rat pituitary cells in vitro, an effect that could be blocked by co-administration of an oxytocin antagonist (Evans \& Catt, 1989; Evans et al., 1989). These studies suggest that endogenous oxytocin could be of physiological importance in the regulation of the LH surge, but other workers have treated rats with either oxytocin or an oxytocin antiserum and reported no change in LH release (Lumpkin et al., 1983; Sarker, 1988). This relationship has not been investigated in detail in ewes, although Sheldrick \& Flint (1990) found that a relatively low dose $\left(3 \mathrm{nmol} \mathrm{h}^{-1}\right.$ ) oxytocin infusion had no effect on LH secretion during the luteal phase. In their study one ewe that underwent luteolysis during treatment had a normal LH surge. These results agree with our own more extensive LH measurements in which we also found no effect of oxytocin infusion on any parameter of LH secretion. The differences from the rat studies could be due to species variation, but may also be attributable to dose: in the present experiment, infusion concentrations of oxytocin were kept within the physiological range for the peripheral circulation.

It is not clear from our previous immunization study (Wathes et al., 1989) whether the increase in gonadotrophin secretion observed in this instance resulted from a direct influence on the hypothalamo-pituitary system or via a change in feedback from the ovary. The same problem pertains to a variety of other studies in rodents that report effects of oxytocin on ovarian function. Early work on the rabbit found that treatment with oxytocin or oxytocin antiserum shortly before mating or hCG treatment blocked ovulation (Brinkley \& Nalbandov, 1963; Roca et al., 1978). Robinson et al. (1985) found that administration of oxytocin to cyclic mice in early pro-oestrus induced more preantral follicles and an earlier ovulation than in control mice, and similar experiments in rats advanced the time of ovulation by about $3 \mathrm{~h}$ (Robinson \& Evans, 1991). However, all oxytocin-treated ewes in the present experiment ovulated, and the histological appearance of the corpus luteum approximately one day after ovulation did not differ following treatment. These data suggest that a raised circulating oxytocin concentration does not have a major influence on the process of ovulation in ewes.

The oxytocin-infused ewes came into oestrus significantly earlier than the controls. In a previous experiment with similar Clun Forest ewes, no control animal showed oestrus until at least $48 \mathrm{~h}$ after cloprostenol treatment (mean $60 \pm 3.5 \mathrm{~h}$ ) (Wathes et al., 1989). In the present experiment all the oxytocin-infused animals were already in oestrus at $48 \mathrm{~h}$ compared with only one control ewe. This difference could have been mediated via an earlier rise in follicular oestradiol secretion in treated ewes; alternatively, it could represent a direct action of oxytocin on the brain, as there is increasing evidence in rodents that central oxytocin release may mediate some of the behavioural effects of gonadal steroids (Caldwell et al., 1986; Arletti \& Bertolini, 1985). Behavioural effects of oxytocin have also been demonstrated in ewes in which intracerebroventricular oxytocin administration promotes maternal behaviour (Kendrick et al., 1987).

We also used the present experiment to examine a possible influence of oxytocin on the regulation of its own receptor. Oxytocin infusion during the luteal phase blocks luteolysis and hence the rise in oxytocin receptor concentration normally associated with luteal regression (Flint \& Sheldrick, 1985). However, both that study and the present one have shown that oxytocin receptors do develop in the presence of maintained high oxytocin concentrations if luteolysis is initiated with exogenous $\mathrm{PGF}_{2 \alpha}$. Sheldrick \& Flint (1986) found that treatment of ovariectomized ewes with two bolus injections of $1 \mu \mathrm{g}$ oxytocin at $1-6 \mathrm{~h}$ intervals decreased endometrial PGF $_{2 a}$ release in response to the second challenge, but this appeared to have been mediated at a postreceptor level as receptor concentrations were unaltered. It is therefore unlikely that the secretion of oxytocin by the corpus luteum of ewes downregulates its own receptor and indeed we found higher endometrial receptor concentrations in infused animals. This increase could have been caused by marginally lower progesterone concentrations in treated animals (see Fig. 1) (Vallet et al., 1990; Wathes et al., 1991); alternatively, it is possible that the infusion causes a decrease in the rate of receptor internalization and degradation. Whereas endometrial oxytocin receptor concentrations were increased by the infusion, myometrial concentrations were unaffected. We have previously observed small but 
consistent differences in the timing of the appearance and disappearance of the two receptor populations around oestrus (V. J. Ayad \& E. L. Matthews, unpublished observations). In addition the localization of the receptors within the endometrium changes at different stages of the oestrous cycle (Ayad et al., 1991). These observations suggest that factors in addition to the circulating steroid concentration differentially regulate expression of the oxytocin receptor in endometrial and myometrial tissues.

Finally, oxytocin infusion had no effect on mid-luteal phase progesterone concentrations, in accord with our previous studies in cattle (Gilbert et al., 1989). There is still controversy about whether oxytocin has a direct influence on ruminant luteal progesterone synthesis, with different authors reporting stimulatory, inhibitory or no effects on cultures of bovine and ovine luteal cells (Tan et al., 1982; Rodgers et al., 1985; Schams, 1987; Barrett \& Wathes, 1990). Results may depend on the stage of the cycle from which cells are obtained, with Schams (1987) reporting that young corpora lutea were particularly sensitive. The inhibitory effect of oxytocin treatment on corpus luteum development in the early luteal phase in cattle is long established (Armstrong \& Hansel, 1959). Although oxytocin injection does not cause early luteal regression in ewes (Milne, 1963; Hatjiminaoglou et al., 1979), oxytocin infusion does delay the rise in progesterone concentration (Wathes et al., 1991). Our previous study was not designed to show whether this was the result of delayed ovulation or a direct action on the corpus luteum. The present experiment suggests that the latter is most likely as ovulation occurred at the normal time, and the secretion pattern of LH, the primary luteotrophic agent in the ewe, was unaffected.

We thank R. Francis and his staff for care of the animals, Hoechst (Frankfurt, Germany) for donation of the oxytocin, M. L. Wild and M. Kumari for skilled technical assistance, M. G. Hunter and M. Fray for provision of the LH RIA reagents, C. M. Wathes for statistical analyses, R. B. Barlow for analysis of the binding data, C. L. Gilbert for surgical assistance and J. Hood for typing the manuscript. The work was supported by grants from the AFRC and Wellcome Trust.

\section{References}

Arletti, R. \& Bertolini, A. (1985) Oxytocin stimulates lordosis behaviour in female rats. Neuropeptides $\mathbf{6}$, 247-254.

Armstrong, D.T. \& Hansel, W. (1959) Alteration of the bovine estrous cycle with oxytocin. Journal of Dairy Science 42, 533-542.

Auletta, F.J. \& Flint, A.P.F. (1988) Mechanisms controlling corpus luteum function in sheep, cows, nonhuman primates and women especially in relation to the time of luteolysis. Endocrine Reviews 9, 88-105.

Ayad, V.J.\& Wathes, D.C. (1989) Characterization of endometrial and myometrial oxytocin receptors in the nonpregnant ewe. Journal of Endocrinology 123, $11-18$.

Ayad, V.J., Matthews, E.L., Wathes, D.C., Parkinson, T.J. \& Wild, M.L. (1991) Autoradiographic localization of oxytocin receptors in the endometrium during the oestrous cycle of the ewe. Journal of Endocrinology 130, 199-206.

Barrett, J. \& Wathes, D.C. (1990) The effect of oxytocin on progesterone secretion and of $\mathrm{PGF}_{2 \mathrm{a}}$ on oxytocin secretion from bovine luteal and granulosa cells in culture. Animal Reproduction Science 22, 297-309.

Brinkley, H.J. \& Nalbandov, A.V. (1963) Effect of oxytocin on ovulation in rabbits and rats. Endocrinology 73, 515-517.

Caldwell, J.D., Prange, A.R. \& Pederson, C.A. (1986) Oxytocin facilitates the sexual receptivity of estrogentreated female rats. Neuropeptides 7, 175-189.
Engstrom, T., Atke, A. \& Vilhardt, H. (1988a) Receptorbinding characteristics and contractile responsiveness of the myometrium following prolonged infusion of bradykinin and oxytocin in rats. Journal of Endocrinology 118, 81-85.

Engstrom, T., Atke, A. \& Vilhardt, H. (1988b) Oxytocin receptors and contractile response of the myometrium after long term infusion of prostaglandin $F_{2 \alpha}$, indomethacin, oxytocin and an oxytocin antagonist in rats. Regulatory Peptides 20, 65-72.

Evans, J.J. \& Catt, K.J. (1989) Gonadotrophin-releasing activity of neurohypophysial hormones: II. The pituitary oxytocin receptor mediating gonadotrophin release differs from that of corticotrophs. Journal of Endocrinology 122, 107-116.

Evans, J.J., Robinson, G. \& Catt, K.J. (1989) Gonadotrophin-releasing activity of neurohypophysial hormones: I. Potential for modulation of pituitary hormone secretion in rats. Journal of Endocrinology 122, 99-106.

Flint, A.P.F. \& Sheldrick, E.L. (1982) Ovarian secretion of oxytocin is stimulated by prostaglandin. Nature 297, 587-588.

Flint, A.P.F. \& Sheldrick, E.L. (1985) Continuous infusion of oxytocin prevents induction of uterine oxytocin receptor and blocks luteal regression in cyclic ewes. Journal of Reproduction and Fertility 75, 623631 . 
Foster, J.P. \& Crighton, D.B. (1974) Luteinizing hormone ( $\mathrm{LH}$ ) release after single injections of synthetic LH-releasing hormone ( $\mathrm{LH}-\mathrm{RH})$ in the ewe at three different reproductive stages and comparison with natural LH release at oestrus. Theriogenology 2, $87-100$.

Gilbert, C.L., Lamming, G.E., Parkinson, T.J., Flint, A.P.F. \& Wathes, D.C. (1989) Oxytocin infusion from Day 10 after oestrus extends the luteal phase in non-pregnant cattle. Journal of Reproduction and Fertility 86, 203-210.

Gilbert, C.L., Cripps, P.J. \& Wathes, D.C. (1992) Effect of oxytocin on the pattern of electromyographic activity in the oviduct and uterus of the ewe around oestrus. Reproduction, Fertility and Development 4, 193-203.

Hatjiminaoglou, I., Alifakiotis, T. \& Zervas, N. (1979) The effect of exogenous oxytocin on estrous cycle length and corpus luteum lysis in ewes. Annales de biologie animale, biochimie et biophysique 19 (2A), 355-365.

Johnston, C.A. \& Negro-Vilar, A. (1988) Role of oxytocin on prolactin secretion during proestrus and in different physiological and pharmacological paradigms. Endocrinology 122, 341-350.

Kendrick, K.M., Keverne, E.B. \& Baldwin, B.A. (1987) Intracerebroventricular oxytocin stimulates maternal behaviour in the sheep. Neuroendocrinology 46, 56-61.

Lumpkin, M.D., Samson, W.K. \& McCann, S.M. (1983) Hypothalamic and pituitary sites of action of oxytocin to alter prolactin secretion in the rat. Endocrinology 112, 1711-1717.

MeCracken, J.A., Schramm, W. \& Okvlicz, W.C. (1984) Hormone receptor control of pulsatile secretion of PGF $_{2 a}$ from the ovine uterus during luteolysis and its abrogation in early pregnant ewes. Animal Reproduction Science 7, 31-55.

McLeod, B.J., Haresign, w. \& Lamming, G.E. (1982) Response of seasonally anoestrous ewes to smalldose multiple injections of GnRH with and without progesterone pretreatment. Journal of Reproduction and Fertility 65, 223-230.

Martini, L., Mira, L., Pecile, A. \& Saito, S. (1959) Neurohypophysial hormones and release of gonadotrophins. Journal of Endocrinology 18, 245-250.

Milne, J.A. (1963) Effects of oxytocin on the oestrous cycle of the ewe. Australian Veterinary Journal 39, $51-52$.

Robinson, G. \& Evans, J.J. (1990) Oxytocin has a role in gonadotrophin regulation in rats. Journal of Endocrinology 125, 425-432.

Robinson, G. \& Evans, J.J. (1991) Oxytocin influences preovulatory follicular development and advances ovulation in rats. Acta Endocrinologica 125, 109-112.

Robinson, G., Evans, J.J. \& Foster, M.E. (1985) Oxytocin can affect follicular development in the adult mouse. Acta Endocrinologica 108, 273-276.

Roca, R.A., Garófalo, E.G., Martino, I., Piriz, H., Rieppi, G., Maraffi, M., Ohahian C. \& Gadola, L. (1978) Effect of oxytocin antiserum and of indomethacin on hCG induced ovulation in the rabbit. Biology of Reproduction 19, 552-557.
Rodgers, R.J., O'Shea, J.D. \& Findlay, J.K. (1985) Do small and large luteal cells of the sheep interact in the production of progesterone? Journal of Reproduction and Fertility 75, 85-94.

Sarkar, D.K. (1988) Immunoneutralization of oxytocin attenuates preovulatory prolactin secretion during proestrus in the rats. Neuroendocrinology 48, 214 216.

Schams, D. (1987) Luteal peptides and intercellular communication. Journal of Reproduction and Fertility Supplement 34, 87-99.

Sheldrick, E.L. \& Flint, A.P.F. (1985) Endocrine control of uterine oxytocin receptors in the ewe. Journal of Endocrinology 106, 249-258.

Sheldrick, E.L. \& Flint, A.P.F. (1986) Transient uterine refractoriness after oxytocin administration in ewes. Journal of Reproduction and Fertility 77, 523-529.

Sheldrick, E.L. \& Flint, A.P.F. (1990) Effect of continuous infusion of oxytocin on prostaglandin $\mathrm{F}_{2 a}$ secretion and luteolysis in the cyclic ewe. Reproduction, Fertility and Development 2, 89-99.

Tan, G.J.S., Tweedale, R. \& Biggs, J.S.G. (1982) Effects of oxytocin on the bovine corpus luteum of early pregnancy. Journal of Reproduction and Fertility 66, 75- 78 .

Vallet, J.L., Lamming, G.E. \& Batten, M. (1990) Control of endometrial oxytocin receptor and uterine response to oxytocin by progesterone and oestradiol in the ewe. Journal of Reproduction and Fertility $\mathbf{9 0}$, 625-634.

Wallace, J.M., Martin, G.B. \& McNeilly, A.S. (1988) Changes in the secretion of LH pulses, FSH and prolactin during the preovulatory phase of the oestrous cycle and the influence of treatment with bovine follicular fluid during the luteal phase. Journal of Endocrinology 116, 123-135.

Wathes, D.C. (1984) Possible actions of gonadal oxytocin and vasopressin. Journal of Reproduction and Fertility 71, 315-345.

Wathes, D.C. (1989) Oxytocin and vasopressin in the gonads. Oxford Reviews in Reproductive Biology 11, 225-283.

Wathes, D.C. \& Swann, R.W. (1982) Is oxytocin an ovarian hormone? Nature 297, 225- 227.

Wathes, D.C., Guldenaar, S.E.F., Swann, R.W., Webb, R., Porter, D.G. \& Pickering, B.T. (1986) A combined radioimmunoassay and immunocytochemical study of ovarian oxytocin production during the periovulatory period in the ewe. Journal of Reproduction and Fertility 78, 167-183.

Wathes, D.C., Ayad, V.J., McGoff, S.A. \& Morgan, K.L. (1989) Effect of active immunization against oxytocin on gonadotrophin secretion and the establishment of pregnancy in the ewe. Journal of Reproduction and Fertility 86, 653-664.

Wathes, D.C., Ayad, V.J., Gilbert, C.L., McGoff, S.A. \& Wathes, C.M. (1991) Influence of oxytocin infusion during oestrus and the early luteal phase on progesterone secretion and the establishment of pregnancy in ewes. Journal of Reproduction and Fertility 92, 383-391.

Received 15 October 1991 